\title{
Assessing progress in the national health financing system towards universal health coverage in Iran: a mixed-method study protocol
}

\author{
Mina Anjomshoa ${ }^{1}$, Ali Akbari Sari ${ }^{1 *}$ and Amirhossein Takian ${ }^{1,2,3}$
}

\begin{abstract}
Introduction: Health financing systems have a key role in achieving universal health coverage (UHC) across the globe. However, little is known about how best to monitor health financing system progress towards UHC, especially in low- and middle-income countries. This is a protocol of a study that will aim to assess health financing system progress towards achieving UHC in Iran.

Methods: An explanatory mixed-method approach will be used in two phases. In the quantitative phase, the performance of the Iranian health financing system will be assessed using a well-established set of indicators to draw on progress over 5 -year intervals starting in the year 2000 up to the present. Data will be extracted from the global health expenditure database using a specific form and will be classified in accordance with each indicator. A qualitative phase will then take place considering the Kutzin et al. framework and by using health financing progress matrices. The qualitative phase will consist of two successive stages; first, a descriptive overview on the major health coverage schemes along with key attributes of each scheme. This initial mapping will be the underlying background for the second stage. In the second stage, the matrices comprised of a series of questions and relevant to the core functions of health financing and cross-cutting options will be invested in enhancing the evaluation of the ongoing reforms or policies. In this phase, data will be collected by reviewing national policy documents and in-depth interviews with key informants who will be recruited using purposive sampling. Finally, a policy discussion with key stakeholders will be held in order to review and verify the consistency between the current health financing policy and UHC goals.

Discussion: This study will provide a comprehensive image about the current status of the national health financing system progress towards achieving UHC in Iran. Such assessment will give detailed insight about the performance of the current financing system through identifying encountered challenges. Furthermore, some other defects in the design of the financing system are expected to appear. In all likelihood, the results will be fruitful enough to make informed decisions about interventions and policies in relation to UHC.

(Continued on next page)
\end{abstract}

\footnotetext{
* Correspondence: akbarisari@tums.ac.ir

1 Department of Health Management and Economics, School of Public Health, Tehran University of Medical Sciences, Tehran, Iran

Full list of author information is available at the end of the article
}

C C The Author(s). 2021 Open Access This article is licensed under a Creative Commons Attribution 4.0 International License, which permits use, sharing, adaptation, distribution and reproduction in any medium or format, as long as you give appropriate credit to the original author(s) and the source, provide a link to the Creative Commons licence, and indicate if changes were made. The images or other third party material in this article are included in the article's Creative Commons licence, unless indicated otherwise in a credit line to the material. If material is not included in the article's Creative Commons licence and your intended use is not permitted by statutory regulation or exceeds the permitted use, you will need to obtain permission directly from the copyright holder. To view a copy of this licence, visit http://creativecommons.org/licenses/by/4.0/ The Creative Commons Public Domain Dedication waiver (http://creativecommons.org/publicdomain/zero/1.0/) applies to the data made available in this article, unless otherwise stated in a credit line to the data. 
(Continued from previous page)

Ethics and dissemination: The study protocol has been approved by the Ethics Committee for Research at Tehran University of Medical Sciences. Informed consent will be obtained from all key informants and the data will be collected and transcribed anonymously in order to maintain utmost confidentiality. The results will be disseminated in peer-reviewed journals and presented in national and international conferences and meetings.

Keywords: Health financing system, Universal health coverage, Iran

\section{Introduction}

In September 2015, the United Nations General Assembly introduced a broad and universal policy agenda entitled Transforming Our World: The 2030 Agenda for Sustainable Development. This agenda has embraced 17 sustainable development goals (SDGs) involving 169 integrated and comprehensive targets. SDG3, encompassing 13 interrelated targets, has been adopted based on its endeavour to ensure healthy lives and promote well-being for all people at all ages $[1,2]$. Stemmed from the Alma Ata declaration, universal health coverage (UHC) became one of the intrinsic targets generally, and particularly in SDG3 [3-5], as it contributes to improving the access of individuals and communities to essential health services $[6,7]$.

According to $\mathrm{WHO}$, UHC has been accurately defined as a desired health system outcome that reflects its capacity in responding to all people's needs, any time and anywhere, without financial hardship. UHC includes a full range of services such as promotion, prevention, treatment, rehabilitation and palliative care [8]. It should be noted that UHC does not necessarily mean the provision healthcare services for free, rather, it focuses on enhancing access without financial hardship [9]. Accordingly, the 'UHC cube' was used in the World Health Report 2010, and reflects three distinct dimensions of coverage, namely population coverage, service coverage and financial coverage [10] (Fig. 1). These three dimensions of the cube represent the policy choices that might be prioritised and implemented to address the gap in the answers of the three critical questions of who is covered, which services are covered and how much is paid out-of-pocket [11]. Therefore, UHC as a concept, can act a key role in accomplishing three main goals of the health system, that is, equity in access to health services, quality of care and financial protection [11]. Health system strengthening is one of main pillars when moving towards UHC, and needs countries to work on this aim [7, 12]. In order to do so, special attention should be paid to the building blocks of the health system, including governance, service delivery, financing, workforce, medicines and technologies, and information $[2,12,13]$. Undoubtedly, health financing is of a particular importance through influencing the three UHC dimensions of equity, quality, and financial protection as well as of the SDG3 overall [12]. Hence, United Nations member countries have highlighted health financing as a principal factor to avoid financial hardship and reach the universal coverage [6].

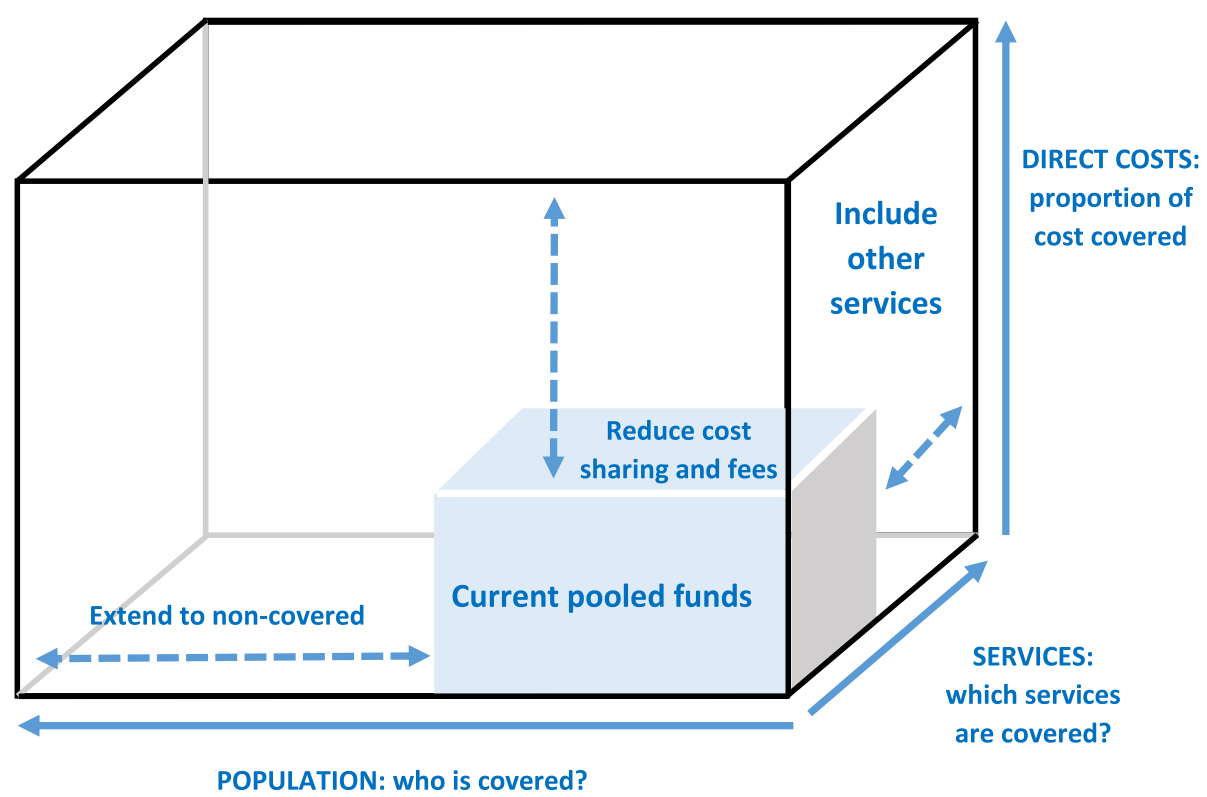

Fig. 1 Universal health coverage (UHC) cube 
Little is known about the best way to assess the capacity of health financing systems to achieve UHC. To achieve this, we have to grasp the current situation and know what is needed to bring about UHC into reality [14]. Systemically, the assessment of health financing systems is an invaluable guideline for policy dialogue underpinning the national health plan related to UHC and its budget in particular [5].

According to the joint report released by $\mathrm{WHO}$ and the World Bank in 2017, Iran is categorized as a low-performing, low- and middle-income country with respect to financial protection [2]. Figure 2 describes the financial protection indicators in Iran and their trends during the last years. Although, UHC was prioritized in the country to be achieved by 2025 [15], Iran has encountered many challenges and financial hardship [15-30] (Table 1). To cope with these circumstances, the government has launched a wide range of health financing reforms in the recent years (Fig. 3).

To the best of our knowledge, this is the first study to assess the capacity of the national health financing system for achieving UHC in Iran. The results of this study might assist policy-makers to design new policies towards achieving UHC in Iran.
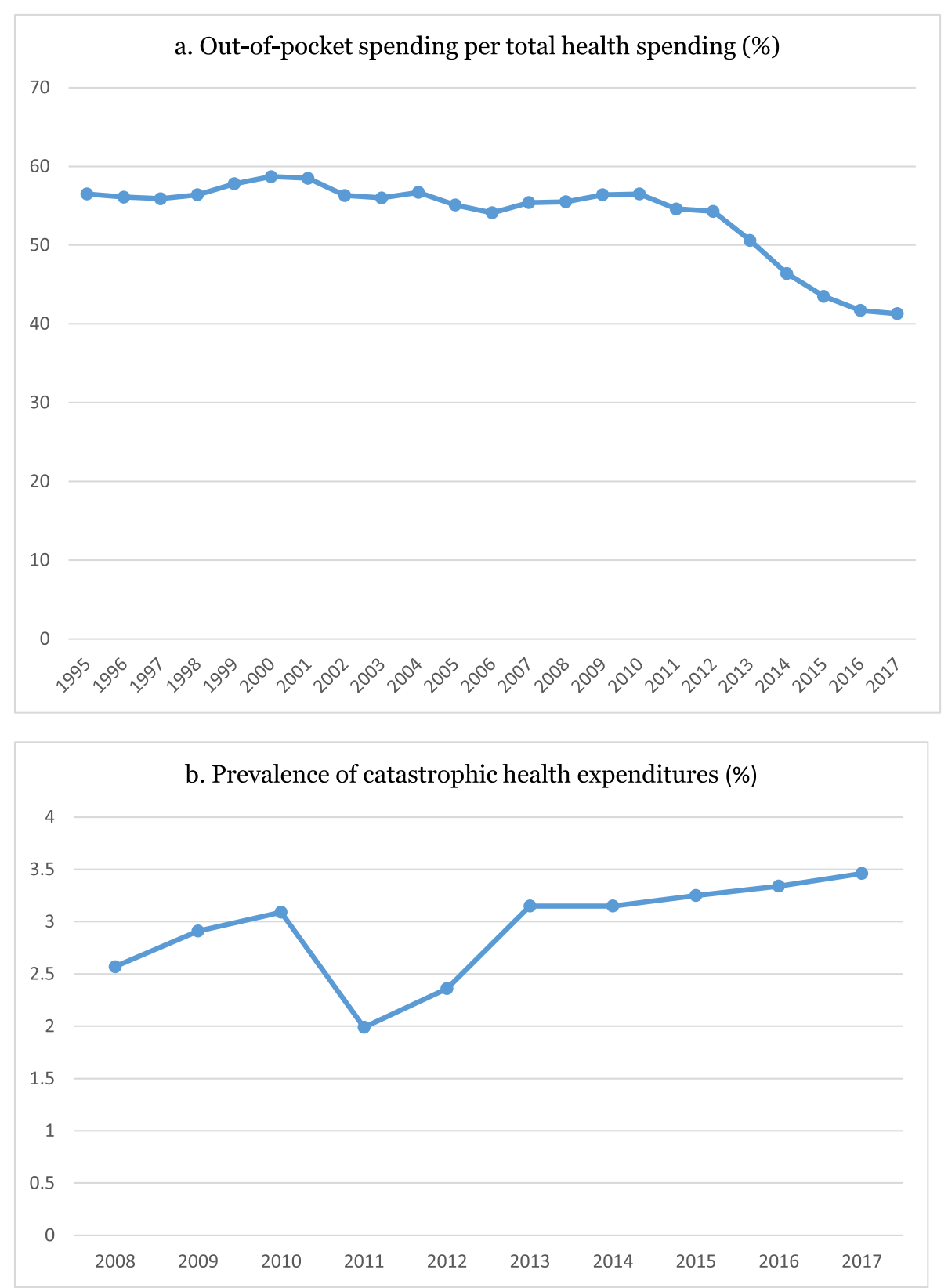

Fig. 2 Prevalence of out-of-pocket spending and catastrophic health expenditures in Iran 
Table 1 The challenges of health financing system in Iran

\begin{tabular}{ll}
\hline Health financing challenges & References \\
\hline Catastrophic costs & {$[16-19]$} \\
Low level of sustainability & {$[15,20-22]$} \\
$\begin{array}{l}\text { Deficit and expensive payment system, } \\
\text { relied on fee-for-service }\end{array}$ & {$[15,23-25]$} \\
$\begin{array}{l}\text { Inadequate share of the public sector in } \\
\text { total health expenditures }\end{array}$ & {$[16]$} \\
$\begin{array}{l}\text { Fragmentation of revenue sources and } \\
\text { pooling }\end{array}$ & {$[15,23,24,26]$} \\
Low level of efficiency & {$[24]$} \\
Existence of informal payments & {$[27,28]$} \\
Increased treatment costs & {$[16]$} \\
Ineffective strategic purchasing & {$[15,29,30]$} \\
mechanisms & {$[15]$} \\
Insufficient redistribution of cross-subsidy & \\
between the insurance schemes & {$[16]$} \\
$\begin{array}{l}\text { Differences between tariffs of public and } \\
\text { private services }\end{array}$ & {$[23,24]$} \\
Poor transparency of financial flow &
\end{tabular}

\section{Methods}

\section{Study design}

This explanatory mixed-method study will be comprised of two consecutive phases, namely a quantitative and a qualitative phase. The study design, phases, data collection, and analysis are illustrated in Fig. 4.

\section{Quantitative phase}

Based on our systematic search, we will draw on a set of health financing indicators, introduced by WHO in December 2019 (Additional file 1) [31]. This set of indicators has been adopted from the global health expenditure database (GHED), which depends on the framework of System of Health Accounts 2011 [32, 33]. These indicators are helpful in estimating financial flows, especially financing sources and schemes. In addition, they will propose the rationale, definition and suitable measurement methods to monitor the progress towards UHC, evaluate the impact of health reforms, and compare the results with those of other countries [32].

Data will be extracted from GHED using a specific form designed for this purpose; these data will then be classified according to each indicator. The annual growth rate according to health financing indicators will be presented in 5-year intervals starting from the year 2000. This study will descriptively analyse the secondary aggregated health financing data about Iran. All data will

\begin{tabular}{|c|c|c|c|c|c|c|}
\hline \multirow[t]{2}{*}{$\begin{array}{l}1975 \\
\text { Establishment of S } \\
\text { Security Organizat } \\
\text { Implementation, gene } \\
\text { and expansion of vario } \\
\text { social and health insur } \\
\text { also establishment of } \\
\text { coordinated system in } \\
\text { accordance with the ot } \\
\text { the comprehensive sys } \\
\text { welfare and social secu }\end{array}$} & $\begin{array}{l}\text { cial } \\
\text { in (SSO) } \\
\text { lization, } \\
\text { stypes of } \\
\text { ce, and } \\
\text { vell- } \\
\text { ectives of } \\
\text { it of }\end{array}$ & \multicolumn{2}{|c|}{$\begin{array}{l}1995 \\
\text { Approval of Hospital } \\
\text { Autonomy Policy by } \\
\text { Parliament } \\
\text { Improving the quality and } \\
\text { performance of teaching } \\
\text { hospitals, and reducing their } \\
\text { financial burden on the budget of } \\
\text { Iran's government }\end{array}$} & \multicolumn{2}{|c|}{$\begin{array}{l}2010 \\
\text { Approval of legislation to } \\
\text { merge public health } \\
\text { insurance funds by } \\
\text { Parliament } \\
\text { Defining equal and basic services } \\
\text { for all Iranian citizens and } \\
\text { covering all Iranians under a } \\
\text { single umbrella of basic health } \\
\text { insurance }\end{array}$} & \multirow[t]{2}{*}{$\begin{array}{l}2014 \\
\text { Implementation of Health } \\
\text { Transformation Plan } \\
\text { Increasing the health system } \\
\text { accountability, reducing out-of- } \\
\text { pocket payments, reducing the } \\
\text { proportion of households facing } \\
\text { catastrophic payments, and } \\
\text { improving quality of care }\end{array}$} \\
\hline & $\begin{array}{l}1994 \\
\text { Establis } \\
\text { Services } \\
\text { Organize } \\
\text { Addressin } \\
\text { care servi } \\
\text { universal } \\
\text { governme } \\
\text { employee } \\
\text { Approva } \\
\text { Health A } \\
\text { Increasing } \\
\text { services b } \\
\text { financial } r\end{array}$ & $\begin{array}{l}\text { edical } \\
\text { health } \\
\text { s as } \\
\text { ce for } \\
\text { and self- } \\
\text { al } \\
\text { ment } \\
\text { thcare } \\
\text { tainable }\end{array}$ & $\begin{array}{l}2005 \\
\text { Implen } \\
\text { Purcha } \\
\text { Improvi } \\
\text { by trans } \\
\text { insuran } \\
\text { Welfare } \\
\text { (MoWs }\end{array}$ & $\begin{array}{l}\text { Split } \\
\text { chasing } \\
\text { ealth } \\
\text { istry of } \\
\text { urity }\end{array}$ & $\begin{array}{l}2012 \\
\text { Merger o } \\
\text { funds un } \\
\text { Health In } \\
\text { Organiza } \\
\text { Quantitativ } \\
\text { developme } \\
\text { services, ac } \\
\text { coverage, a } \\
\text { of health se } \\
\text { of-pocket p } \\
\text { overlap in i } \\
\text { and expand } \\
\text { program an }\end{array}$ & \\
\hline
\end{tabular}




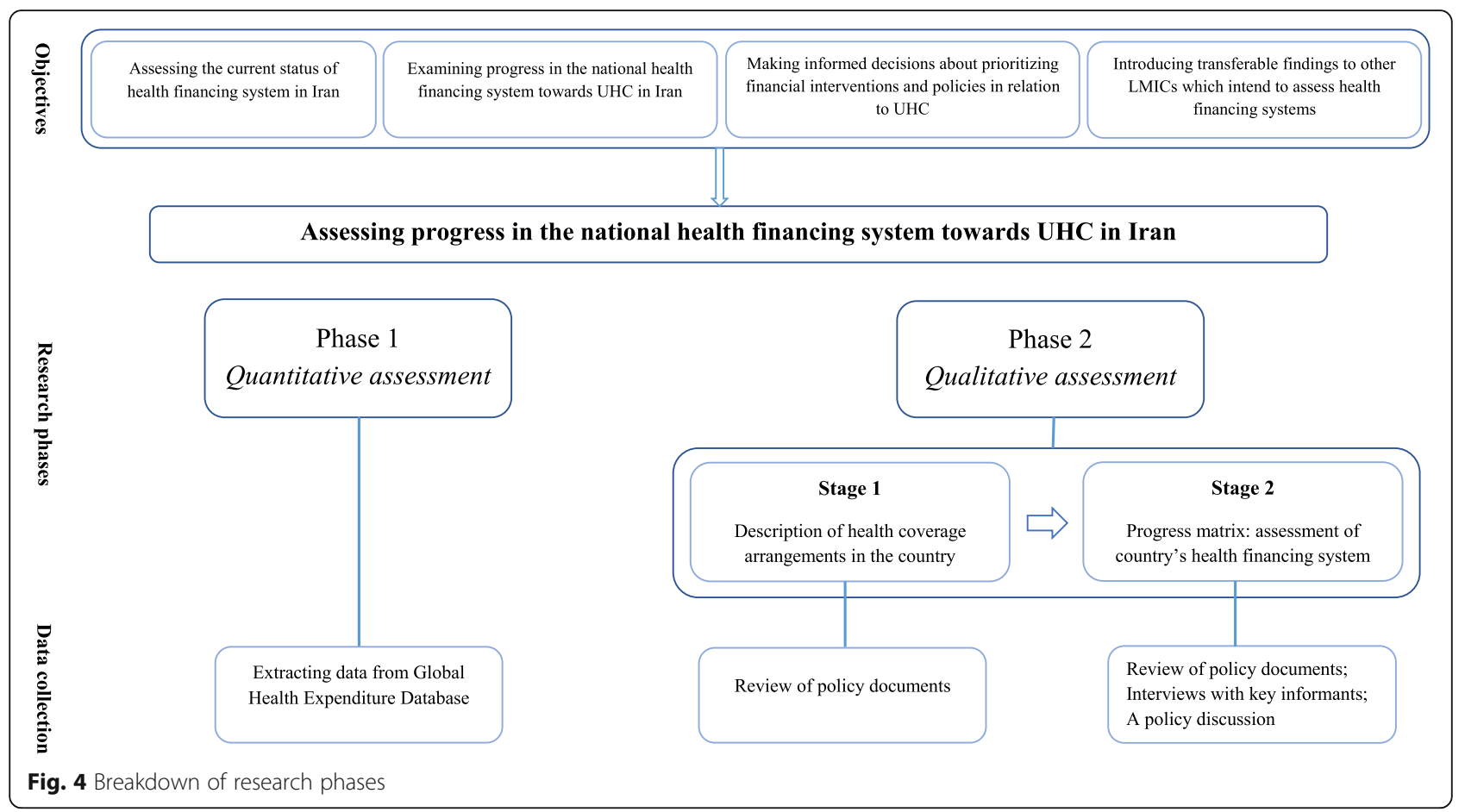

be analysed using STATA. We will generate scatter plots and graphs, and simple calculations will be used to determine the percent change in health financing trends.

\section{Qualitative phase}

Theoretically informed by the Kutzin et al. framework [34], qualitative assessment will be conducted using Health Financing Progress Matrices (HFPMs) [35], which have been developed to appraise the consistency between health financing policy developments and UHC objectives $[35,36]$. These matrices were introduced by the Department of Health Systems Governance and Financing of WHO in December 2019 in order to formulate a framework valid for monitoring and assessing health financing systems. As a result, assessment findings will be combined with information derived from the quantitative phase in order to get a comprehensive and detailed depiction of the current health financing system aims at achieving UHC in Iran.

Qualitative assessment will be undertaken through two successive stages. In the first stage, a descriptive overview of the major health coverage schemes in the country will be outlined along with key attributes of each scheme; thus, this initial mapping will stand as a basis for the second stage. In the second stage, the matrices comprised of a series of questions and relevant to the core functions of health financing and cross-cutting options will be invested in enhancing the evaluation of the ongoing reforms or policies. Figure 5 summarizes the stages and components of HFPMs [37].

The required information will be mostly obtained from secondary sources with careful referral to the supporting documents or related interviews. Reviewing the national documents will be useful in updating knowledge about the health financing policy regarding its formulation, underlying evidence and key actors, and identification of areas in need of revision.

In-depth, face-to-face, and semi-structured interviews will be conducted with key informants in the country, e.g. health financing experts, policy-makers and academics, using an interview guide published by HFPMs. Key informants will be recruited using a purposive sampling technique, and the time and place of interview will be assigned by direct coordination with interviewees. We estimate that approximately 15 interviews will be needed; subsequently, the recruitment of new key informants will continue up to saturation. It is estimated that each interview will last 60-90 minutes.

Informed consent will be obtained from the participants and the interviews will be recorded using a digital recorder and transcribed verbatim directly after the interview. Policy documents and transcripts will be thematically analysed using MAXQDA, a software developed to facilitate data management in qualitative research. Finally, a policy discussion with key stakeholders will be held in order to review and verify the consistency between the current health financing policy and UHC goals. 


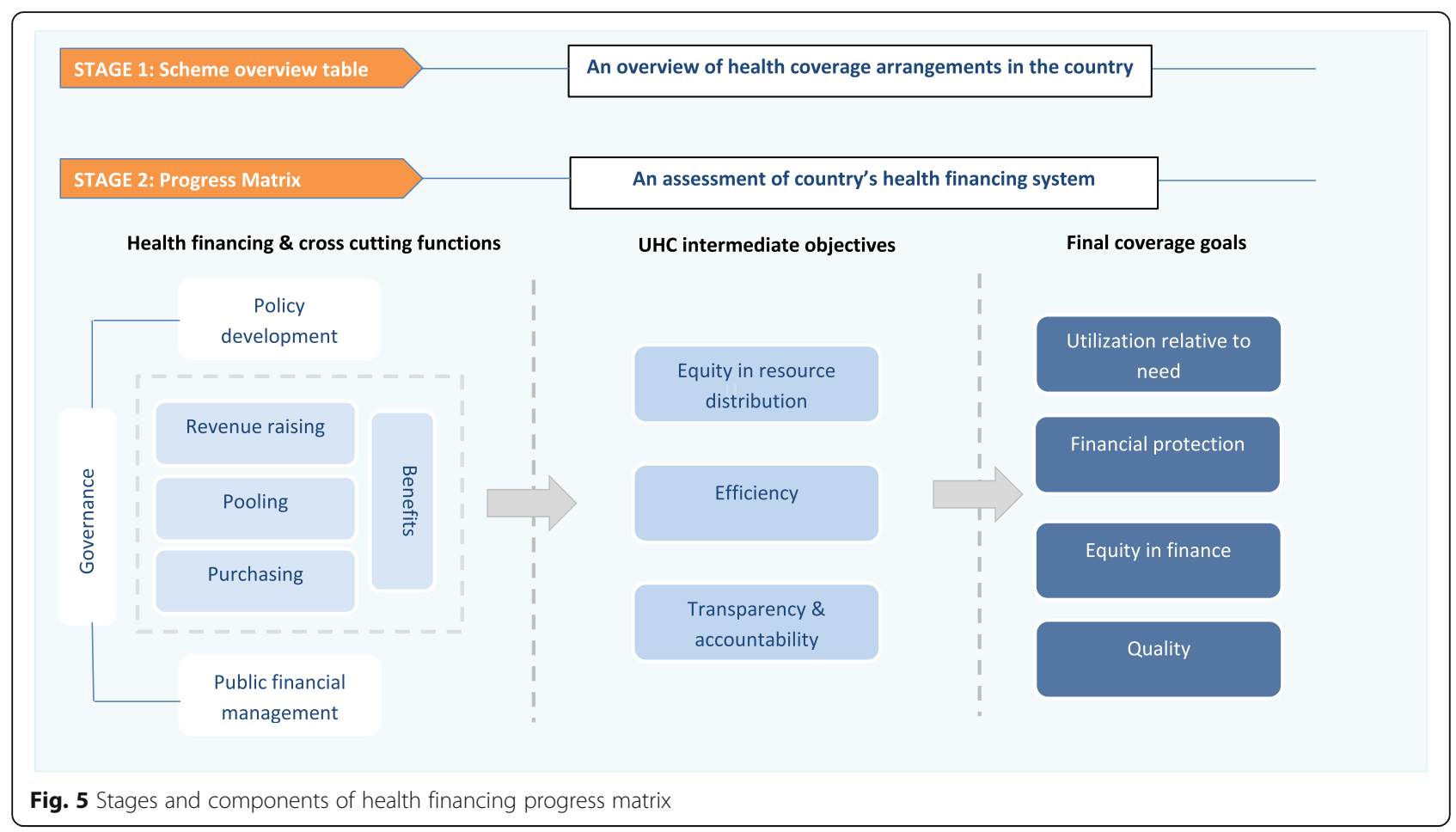

\section{Ethics}

The study protocol has been approved by the Ethics Committee for Research at Tehran University of Medical Sciences. Informed consent will be also obtained from key informants; data will be collected anonymously to maintain utmost confidentiality.

\section{Discussion}

Although there is a global commitment to the UHC approach [38], it has not been fully achieved in any country around the world. Nevertheless, most countries have made relative progress and moved towards UHCrelevant goals [11]. Most countries are deeply working on strengthening their systems to progress towards UHC [7, 12]. Health system strengthening includes enhancing all components of the health system that are central to moving towards UHC, including governance, service delivery, financing, workforce, medicines and technologies, and information $[2,12]$. In particular, the component of health financing has proved to be essential in ensuring effective progress towards UHC, as it impacts three intermediate UHC objectives, namely, efficiency, equity and transparency, and thereby ultimately contributes to the achievement of UHC elements cited in SDG target 3.8 [12]. It is noteworthy that robust health financing structures are essential for achieving UHC [5, 39]. To improve the formulation and implementation of health financing policies, it is fundamental to assess the current status to identify strengths and weaknesses in addition to opportunities and threats.
Such assessment will provide a clear profile about the performance of the existing system and the demanded reforms before navigating towards UHC.

This study is going to fill in a remarkable gap in the literature through usage of a mixed-methods design examining the ongoing status as well as the progress in the national health financing system towards achieving $\mathrm{UHC}$ in Iran. To the best of our knowledge, this is the first study that uses two structured frameworks [31, 37] to assess the Iranian health financing system. By using GHED for monitoring health financing indicators, a quantitative assessment of the health financing system will be undertaken, and trends and changes needed will be acquired. The HFPM framework, as a guide for qualitative assessment, will assist in collecting, organising and interpreting the data in a structured and systematic way.

Although there were several previous attempts to reform the national health financing system, some other defects in its design are expected to appear within the findings of this study. IN all likelihood, the results will be fruitful enough to make informed decisions about financial interventions and policies in relation to UHC in Iran. This will also provide an opportunity to assess whether the existing health financing system is performing well or poorly, a diagnosis of the reasons why, and the challenges the country faces in moving towards UHC and will provide the 'starting point' for a national health financing reform strategy.

Moreover, this study is anticipated to introduce transferable findings to other low- and middle-income countries 
that will embark on assessment and reforming of their health financing systems in order to achieve UHC. The results will be disseminated in peer-reviewed journals and presented in appropriate forums, including national and international conferences and meetings. A series of policy briefs will also be introduced to interested national policymakers in order to promote the successful design and implementation of national health financing policies.

\section{Supplementary information}

Supplementary information accompanies this paper at https://doi.org/10. 1186/s12961-020-00610-z.

Additional file 1. Health financing indicators

\section{Abbreviations}

UHC: Universal health coverage; GHED: Global Health Expenditure Database HFPMs: Health financing progress matrices; SDGs: Sustainable Development Goals

\section{Acknowledgments}

None.

\section{Authors' contributions}

MA drafted the manuscript and contributed to the conception and design of the study. AAS contributed to the conception of the study, supervised the entire process of design, and the intellectual development of the manuscript; he is the guarantor. AT was advisor in methodology and contributed to intellectual development of manuscript. All authors read and approved the final version of the manuscript.

\section{Funding}

This work was part of a PhD thesis in TUMS. TUMS had no role in study design, collection, analysis, and interpretation of data, writing of the report, or in the decision to submit the report for publication.

\section{Availability of data and materials}

Not applicable.

\section{Ethics approval and consent to participate}

The study protocol has been approved by the Ethics Committee for Research at Tehran University of Medical Sciences. Informed consents will be also obtained from key informants; data will be collected anonymously to maintain utmost confidentiality.

\section{Consent for publication}

Not applicable.

\section{Competing interests}

The authors declare that they have no competing interests.

\section{Author details}

${ }^{1}$ Department of Health Management and Economics, School of Public Health, Tehran University of Medical Sciences, Tehran, Iran. ${ }^{2}$ Department of Global Health and Public Policy, School of Public Health, Tehran University of Medical Sciences, Tehran, Iran. ${ }^{3}$ Health Equity Research Centre (HERC), Tehran University of Medical Sciences, Tehran, Iran.

Received: 4 May 2020 Accepted: 28 July 2020

Published online: 12 January 2021

\section{References}

1. Desa U. Transforming our world: The 2030 agenda for sustainable development. Division for Sustainable Development Goals: New York, NY, USA. 2016. Accessed 20 Apr 2020

2. World Health Organization \& World Bank. Tracking universal health coverage: 2017 global monitoring report. Geneva: World Health
Organization; 2017. http://www.who.int/iris/handle/10665/259817. Accessed 20 Apr 2020.

3. The International Conference on Primary Health Care. Alma Alta declaration. Sept 12, 1978. http://www.who.int/publications/almaata_declaration_en.pdf. Accessed 04 Apr 2020.

4. Robert E, Ridde V, Rajan D, Sam O, Dravé M, Porignon D. Realist evaluation of the role of the Universal Health Coverage Partnership in strengthening policy dialogue for health planning and financing: a protocol. BMJ Open. 2019;9(1):e022345.

5. Dieleman JL, Sadat N, Chang AY, Fullman N, Abbafati C, Acharya P, et al Trends in future health financing and coverage: future health spending and universal health coverage in 188 countries, 2016-40. Lancet. 2018; 391(10132):1783-98.

6. Zhang C, Rahman S, Rahman M, Yawson AE, Shibuya K. Trends and projections of universal health coverage indicators in Ghana, 1995-2030: a national and subnational study 2019.

7. Chu A, Kwon S, Cowley P. Health financing reforms for moving towards universal health coverage in the western pacific region. Health Syst Reform. 2019:5(1):32-47.

8. World Health Organization \& World Bank. Monitoring progress towards universal health coverage at country and global levels: framework, measures and targets. Geneva: World Health Organization; 2014. http://www.who.int/ iris/handle/10665/112824. Accessed 06 Apr 2020.

9. Abou Jaoude GJ, Skordis-Worrall J, Haghparast-Bidgoli H. Measuring financial risk protection in health benefits packages: scoping review protocol to inform allocative efficiency studies. BMJ Open. 2019;9(5): e026554.

10. World Health Organization. The world health report: health systems financing: the path to universal coverage. Geneva: World Health Organization; 2010. http://www.who.int/iris/handle/10665/44371. Accessed 06 Apr 2020.

11. McIntyre D, Kutzin J. Health financing country diagnostic: a foundation for national strategy development. Geneva: World Health Organization; 2016.

12. World Health Organization, Regional Office for the Eastern M. Strengthening health financing systems in the Eastern Mediterranean Region towards universal health coverage: health financing atlas 2018. Cairo: World Health Organization, Regional Office for the Eastern Mediterranean; 2019.

13. Myint C-Y, Pavlova M, Thein K-N-N, Groot W. A systematic review of the health-financing mechanisms in the Association of Southeast Asian Nations countries and the People's Republic of China: lessons for the move towards universal health coverage. PLoS One. 2019;14(6):e0217278.

14. Fullman N, Lozano R. Measurement matters: who and what counts on the road to universal health coverage. Lancet Glob Health. 2020;8(1):e2-3.

15. Doshmangir L, Bazyar M, Majdzadeh R, Takian A. So near, so far: four decades of health policy reforms in Iran, achievements and challenges. Arch Iran Med. 2019:22(10):592-605.

16. Danaei G, Farzadfar F, Kelishadi R, Rashidian A, Rouhani OM, Ahmadnia S, et al. Iran in transition. Lancet. 2019:393(10184):1984-2005.

17. Yazdi-Feyzabadi V, Bahrampour M, Rashidian A, Haghdoost A-A, Javar MA Mehrolhassani $\mathrm{MH}$. Prevalence and intensity of catastrophic health care expenditures in Iran from 2008 to 2015: a study on Iranian household income and expenditure survey. Int J Equity Health. 2018;17(1):44.

18. Rezaei S, Woldemichael A, Hajizadeh M, Kazemi Karyani A. Catastrophic healthcare expenditures among Iranian households: a systematic review and meta-analysis. Int J Hum Rights Healthc. 2019;12(2):105-15.

19. Aryankhesal A, Etemadi M, Mohseni M, Azami-Aghdash S, Nakhaei M. Catastrophic Health Expenditure in Iran: A Review Article. Iran J Public Health. 2018;47(2):166-77.

20. Mousavi SM, Sadeghifar J. Universal health coverage in Iran. Lancet Glob Health. 2016:4(5):e305-e6.

21. Moradi-Lakeh M, Vosoogh-Moghaddam A. Health sector evolution plan in Iran; equity and sustainability concerns. Int J Health Policy Manag. 2015; 4(10):637-40.

22. Javadinasab H, Masoudi Asl I, Vosoogh-Moghaddam A, Najafi B. Sustainable financing of health promotion services in selected countries: best experience for developing countries. Med J Islam Repub Iran. 2019;33:52.

23. Ibrahimipour H, Maleki M-R, Brown R, Gohari M, Karimi I, Dehnavieh R. A qualitative study of the difficulties in reaching sustainable universal health insurance coverage in Iran. Health Policy Plan. 2011:26(6):485-95.

24. Alinia C, Davoodi Lahijan J. Moving toward universal health coverage: four decades of experience from the Iranian health system. Clinicoecon Outcomes Res. 2019;11:651-7. 
25. Sajadi HS, Ehsani-Chimeh E, Majdzadeh R. Universal health coverage in Iran: where we stand and how we can move forward. Med J Islam Repub Iran. 2019;33:9.

26. Bazyar M, Rashidian A, Kane S, Vaez Mahdavi MR, Akbari Sari A, Doshmangir L. Policy options to reduce fragmentation in the pooling of health insurance funds in Iran. Int J Health Policy Manag. 2016;5(4):253-8.

27. Khodamoradi A, Rashidian A, Daryabeygi-Khotbehsara R, Aghlmand S. Evaluation of informal payments to health care professionals and the influential factors in Urmia city hospitals, Iran. J Med Ethics Hist Med. 2018;11.

28. Meskarpour Amiri M, Assari A, Bahadori M, Ravangard R, Hosseini-Shokouh SM. Informal payments for health care in Iran. Int J Health Governance. 2018;23(3):205-15.

29. Kalantari AR, Jafari Sirizi M, Mehrolhassani MH, Dehnavieh R. Challenges of implementation: strategic purchasing in Iran Health Insurance Organization. Int J Health Plann Manag. 2019:34(1):e875-84.

30. Gorji HA, Mousavi S, Shojaei A, Keshavarzi A, Zare H. The challenges of strategic purchasing of healthcare services in Iran Health Insurance Organization: a qualitative study. Electron Physician. 2018;10(2):6299-306.

31. World Health Organization. Technical brief on the indicators published on the World Health Organization's. Global Health Expenditure Database. 2017. http://apps.who.int/nha/database/DocumentationCentre/Index/en. Accessed 20 Apr 2020

32. Global health expenditure database 2018 update. World Health Organization; 2020. https://www.who.int/health_financing/topics/resourcetracking/ghed-update/en/. Accessed 20 Apr 2020.

33. OECD, Eurostat, WHO. A System of Health Accounts. OECD Publishing; 2011. https://doi.org/10.1787/9789264116016-en.

34. Kutzin J, Witter S, Jowett M, Bayarsaikhan D. Developing a national health financing strategy: a reference guide. Geneva: World Health Organization; 2017.

35. World Health Organization. (2019). Assessing country progress in health financing for UHC. https://www.who.int/activities/assessing-progress-inhealth-financing-for-uhc. Accessed 04 Apr 2020.

36. Strengthening health systems through the application of health financing progress matrices: country experience. 5th African Health Economics Association Conference Accra; 2019; Ghana World Health Organization; 2019.

37. World Health Organization. Health financing progress matrix. Geneva: World Health Organization; 2019. https://www.who.int/docs/default-source/healthfinancing/hfpm-stage-2-(v2-2).xlsm?sfvrsn=884c41 ba_2. Accessed 04 Apr 2020

38. Wagstaff A, Neelsen S. A comprehensive assessment of universal health coverage in 111 countries: a retrospective observational study. Lancet Glob Health. 2020;8(1):e39-49.

39. Kutzin J. Health financing for universal coverage and health system performance: concepts and implications for policy. Bull World Health Organ. 2013;91(8):602-11.

\section{Publisher's Note}

Springer Nature remains neutral with regard to jurisdictional claims in published maps and institutional affiliations.

Ready to submit your research? Choose BMC and benefit from:

- fast, convenient online submission

- thorough peer review by experienced researchers in your field

- rapid publication on acceptance

- support for research data, including large and complex data types

- gold Open Access which fosters wider collaboration and increased citations

- maximum visibility for your research: over $100 \mathrm{M}$ website views per year

At $\mathrm{BMC}$, research is always in progress.

Learn more biomedcentral.com/submissions 